\title{
Psychological Wellbeing in Iranian Infertile Women: A Review of the Studies in Iran
}

\author{
Seyedeh Saeedeh Mousavi ${ }^{1}$, ${ }^{*}$ Seyedeh Batool Hasanpoor Azghady ${ }^{2}$
}

\begin{abstract}
Background \& Aims: Recognition of the emotional, social, and mental health of infertile women could contribute to their quality of life. The assessment of psychological wellbeing is considered to be essential in this regard. The present study aimed to provide a comprehensive review of the research focused on the psychological wellbeing of infertile women in Iran.

Materials \& Methods: This review study was conducted to find the studies regarding Iranian infertile women via searching in Persian databases (MagIran, SID, and IranMedex) and English databases (Google Scholar, Web of Science, EMBASE, Medline, PubMed, ScienceDirect, and Scopus) using a combination of Persian keywords, including infertile, infertility, wellbeing, psychological wellbeing, and Iran with no time limitation. In total, 24 related articles were retrieved, 12 of which were specifically focused on the psychological wellbeing of infertile women in Iran and further reviewed.

Results: According to the literature, the psychological wellbeing of infertile women has increased in recent years, and the average psychological wellbeing is reported to be higher in large cities with various ethnicities (especially Persian-speaking ethnicities) compared to smaller cities. In addition, the educational interventions and consultations that have been performed regarding the psychological wellbeing of infertile women using various methods in Iran have largely contributed to the improvement of this factor.

Conclusion: Although the psychological wellbeing of Iranian infertile women has been reported to increase in recent studies, the effects of some demographic variables on the psychological wellbeing of these women have not been adequately investigated in most of the studies in Iran. Therefore, it is recommended that the associations of various demographic characteristics and psychological wellbeing be further explored. It seems that descriptive studies on large sample sizes are required in order to assess the effects of some demographic variables (e.g., education level, ethnicity, and residence) on the psychological wellbeing of infertile women.
\end{abstract}

Keywords: Psychological Wellbeing, Infertile Women, Iran, Review Study

\section{Conflict of Interest: No}

How to Cite: Mousavi SS, Hasanpoor Azghady SB. Psychological Wellbeing in Iranian Infertile Women: A Review of the Studies in Iran. Iran Journal of Nursing. 2019; 32(117):45-57.

Received: 12 Jan 2019

Accepted: 15 Apr 2019

\footnotetext{
1. Assistant Professor, Department of Reproductive Health and Midwifery, Nursing Care Research Center (NCRC), School of Nursing and Midwifery, Iran University of Medical Sciences, Tehran, Iran

${ }^{2}$. Assistant Professor, Department of Reproductive Health and Midwifery, Nursing Care Research Center (NCRC), School of Nursing and Midwifery, Iran University of Medical Sciences, Tehran, Iran (*Corresponding author) Tel: +98-2143651809 $\quad$ Email: hasanpoorbatool@yahoo.com
} 


\title{
بهزيستى روانشناختى در زنان اير انى نابارور: مرورى بر مطالعات انجام شده در ايران
}

\author{
سيده سعيده موسوى'، *سيده بتول حسن يور ازغدى'
}

\begin{abstract}
زمينه و هدف: شناخت ويزَّى هاى عاطفى، اجتماعى و سلامت روان زنان نابارور مى تواند در جهت كمك به كيفيت زندكى آنان كمى كنده باشد. در

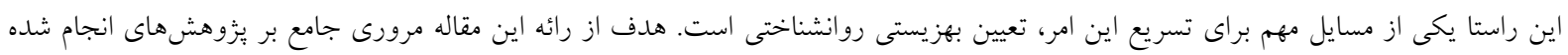

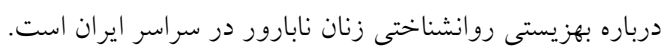

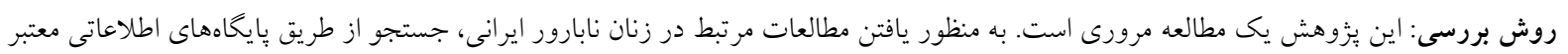

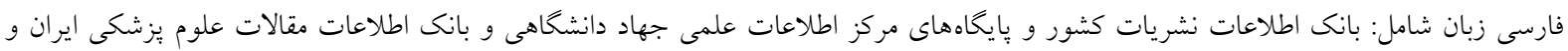
قإيكاههاى انغكليسى زبان شامل: Google Scholar, EMBASE, Web of Science, MEDLINE, Pub Med, Science Direct, Scopus

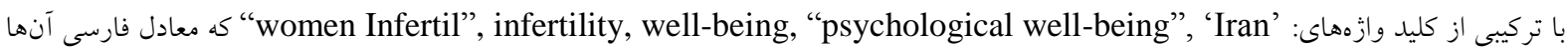

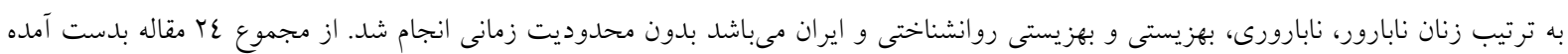

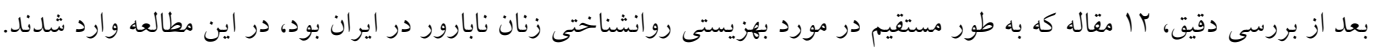

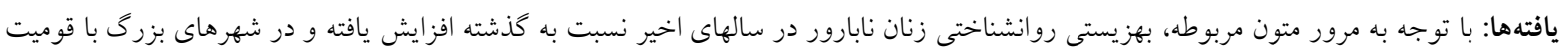

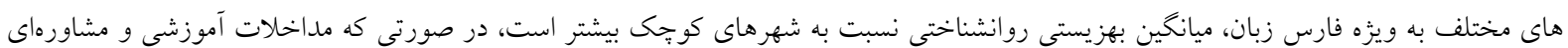

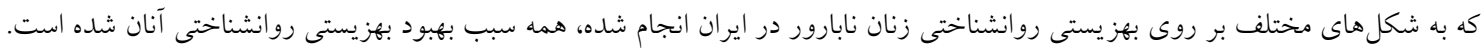

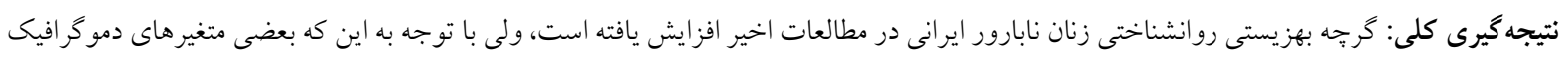

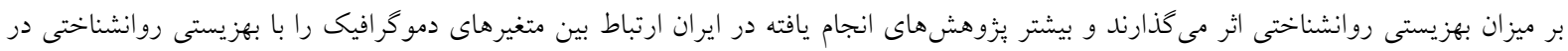

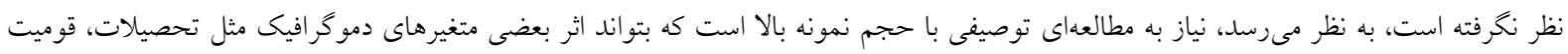

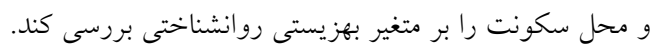

كليد وازهها: بهزيستى روانشناختى، زنان نابارورر، ايران، مقاله مرورى

تعارض منافع: ندارد

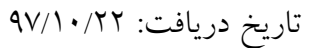

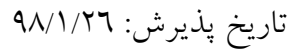

\footnotetext{
'. استاديار تروه مامايى و بهداشت بارورى، مركز تحقيقات مراقبتهاى يرستارى، دانشكده برستارى و مامايى دانشكاه علوم يزشكى خدمات بهداشتى

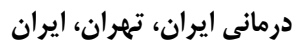

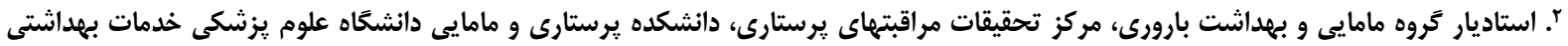


بهزيستى هايينتر اغلب درگير هيجانهاى منفى مانند افسردگى و اضطر اب هستند (11). بهزيستى روانشناختى را تلاش فرد جهت تحقق وابنق Ryff

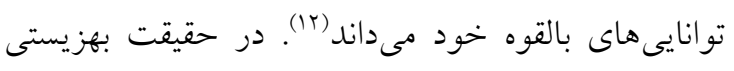

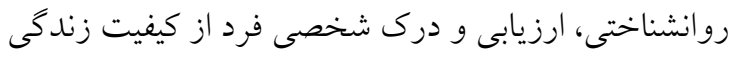
اش شامل كيفيت كنشهاى اجتماعى، روانشناختى و

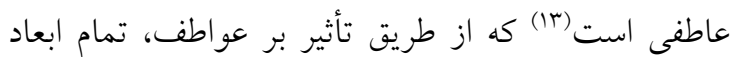

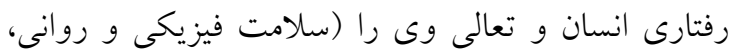

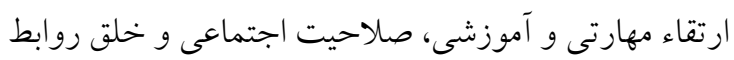

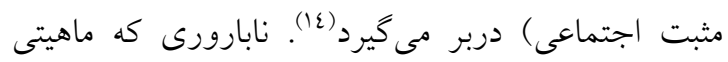

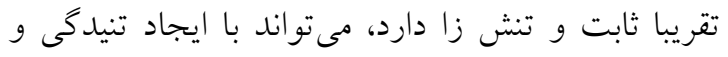

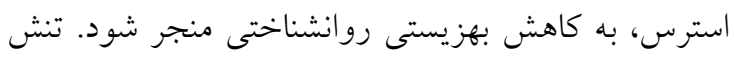
حاصل از نابارورى بر روابط مثبت فردى، اجتماعى و زناشويى كه از حيطههاى بهزيستى روانشناختى است تأثير كذاشته، موجب عدم تعادل روانى زوجين، قطع رابطه بين

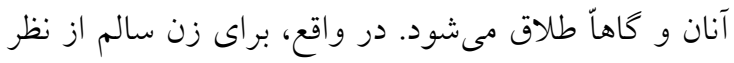

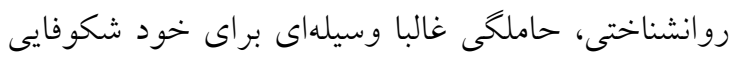

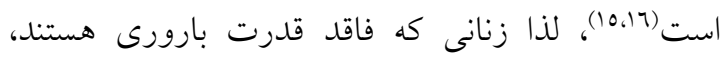
احساس ناتوانى، بىارزشى و عدم كفايت مى كنند و جهون

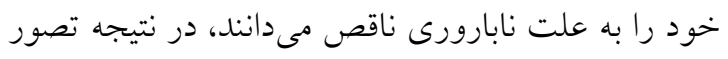

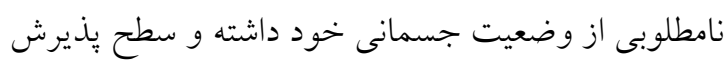

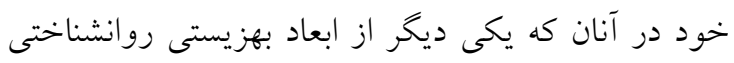

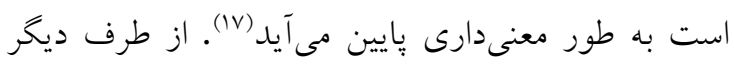

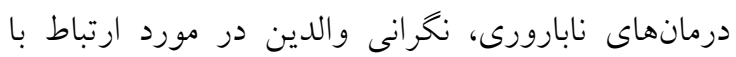

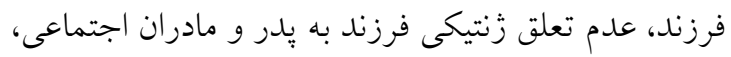
همجنين سردر گمى در مورد صفات يدر در موارد استفاده از اسبرم شخص ثالث بر روى بهزيستى روانشناختى

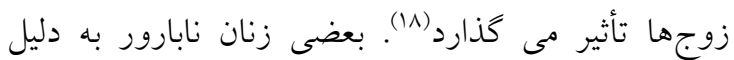

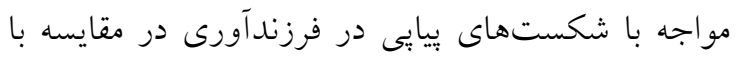
زنان بارور ميزان بالاترى تنش، اضطراب و افسردگى را برائا

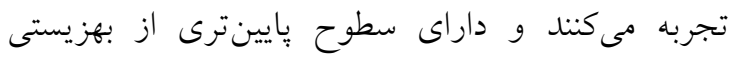

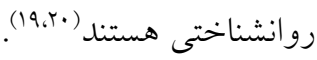

در جو امعى مثل ايران كه يكى از معيارهاى تعريف هويت هبندان

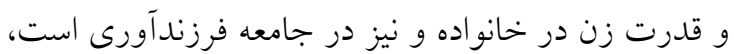

\section{مقدمه - - م}

نابارورى طيف گستردهاى از آسيبهاى روانشناختى مانند كاهش كيفيت زندگى، عزت نفس، رضايت جنسى و افزايش اضطراب و افسردگى را به دنبال دارد و به دليل فشار هيجانى وارده بر روان فرد، تاب آورى شخص را متزلزل كرده و بهزيستى روانشناختى وى را كاهش مى دهد (r-1). شيوع بالاى نابارورى در سراسر جهان ديلده مىشود.

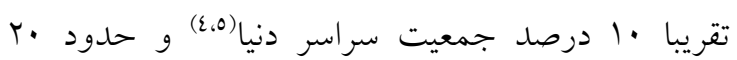
درصد زوجين در كشورهاى بيشرفته با مشكل نابارورى دست به گريبانند(1). در ايران بر اساس نتايج طرح ملى بررسى شيوع نابارورى، نرخ شيوع نابارورى در كل كشور r/T r درصد گزارش شده است كه در شهرها نرخ شيوع 19/9 و در روستاها ب r درصد است كه اين ميزان با ميانكين

جهانى فاصله زيادى دارد (v). امروزه در روانشناسى در مقابل توجه و تمركز سنتى كه به آسيبشناسى و روانشناسى مرضى شده است، ديدگاه جديدى در علوم وابسته به سلامت و در روانشناسى در حال شكل گيرى و گسترش است. در اين ديدگاه و رويكرد علمى، تمركز بر روى سالمتى و بهزيستى از جنبهى مثبت و توضيح و تبيين ماهيت روانشناختى بهزيستى است. ماهيت و ساختار بهزيستى موضوعى است كه از كذشته مورد توجه فيلسوفان و دانشمندان رشته هاى مختلف علمى قرار داشته است و به تازگى در كانون توجه روان شناسى

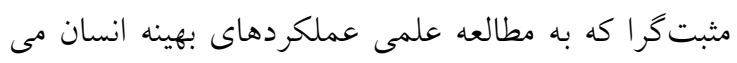

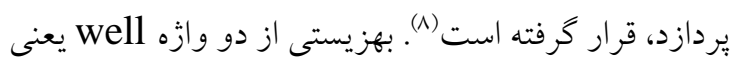

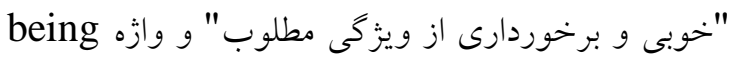

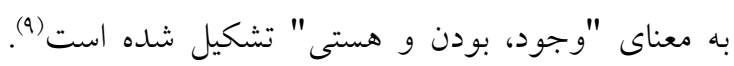
رويكرد بهزيستى روانشناختى، رشد و تحول مشاهده شده در برابر جالش هاى وجودى زندگى را بررسى مى كند و به

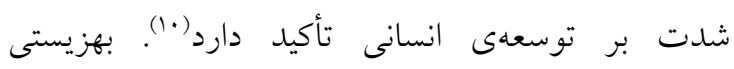
روانشناختى به عنوان يكى سازه جِند بعدى، اجزا شناختى

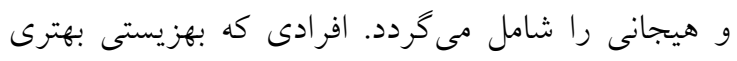
دارند، غالباّ هيجان مثبت دارند و در برخورد با حوادث و اتفاقات نخاهى خوشايند دارند، در حالى كه اشخاص با 
در اين مطالعه مرورى به منظور ياسخ به سئوال يزوهش

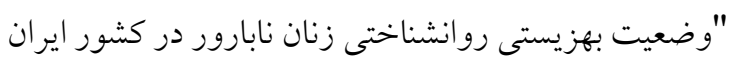
جِكونه است؟" مطالعات مرتبط در زنان نابارور ايرانى از

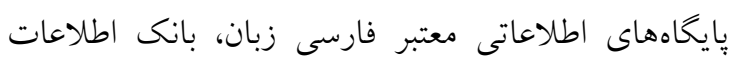

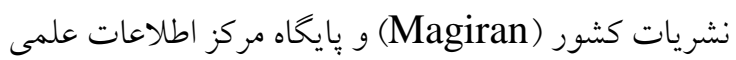
جهاد دانشخاهى (SID) و بانك اطلاعات مقالات علوم

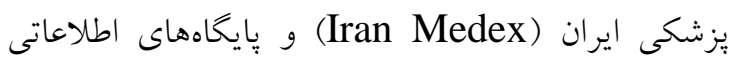

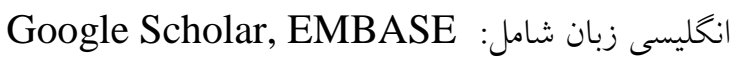
Web of Science, MEDLINE, Pub Med, Science Direct, Scopus

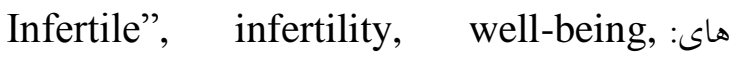
"psychological well-being", "Iran"

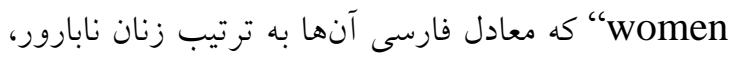

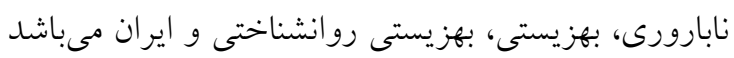

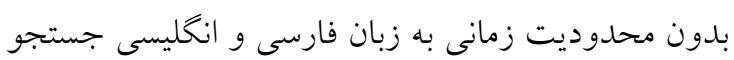
و استفاده شد. معيارهاى ورود به مطالعه شامل: مطالعات

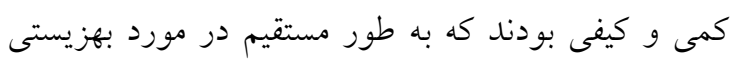
روانشناختى بودند و امكان دسترسى به متن كامل مقاله مهيا

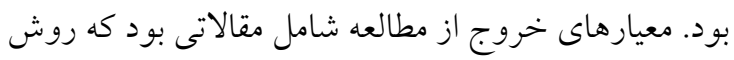

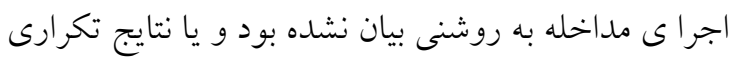

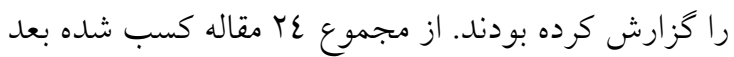
از بررسى دقيق از نظر ارائهى نتايج تكرارى، الب مقاله

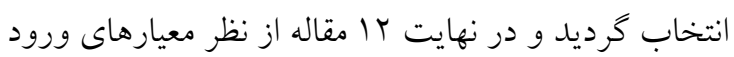
و خروج در اين مطالعه وارد و مورد بررسى قرار كرفتند.

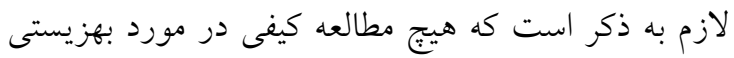
روانشناختى زنان نابارور در ايران انجام نشده بود. (شكل
زنانى كه با معضل نابارورى روبرو هستند، مشكلات خانوادكى و اجتماعى بيشترى نسبت به به مردان نابارور

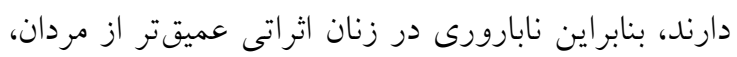

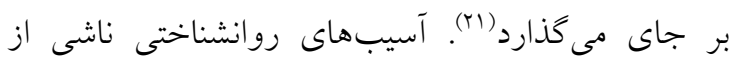

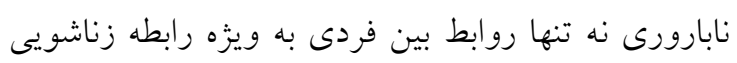

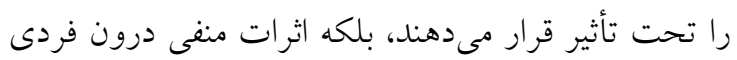

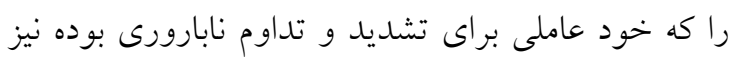

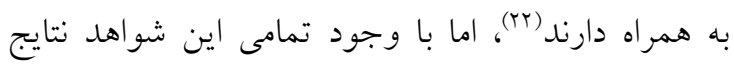
بعضى مطالعات ديخر در ايران و نقاط ديخر جهان نشان داده است كه بهزيستى روانشناختى در دو گروه بارور و

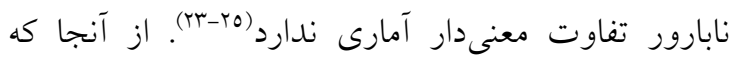

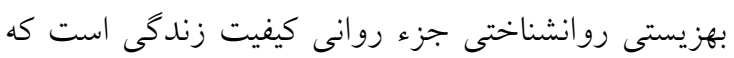
به عنوان درك فرد از زندگى خودش در حيطه رفتارهاى

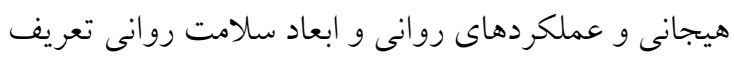

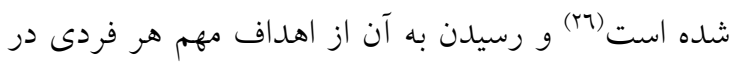
زندگى است و از طرف ديخر يكى از جنبههاى مهم توانمند

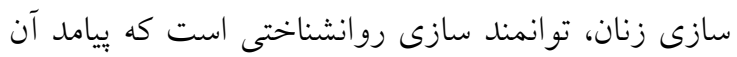

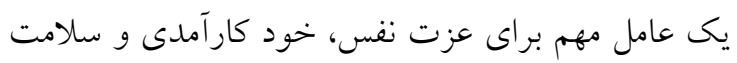

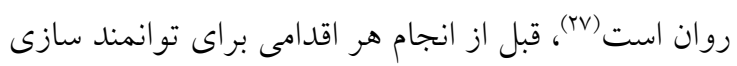

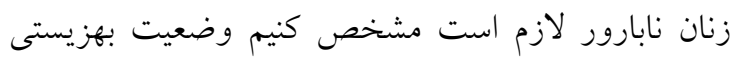

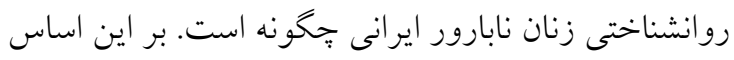

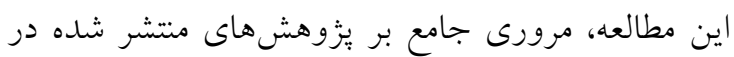
زمينه بهزيستى روانشناختى در زنان نابارور ايرانى است.

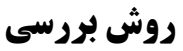




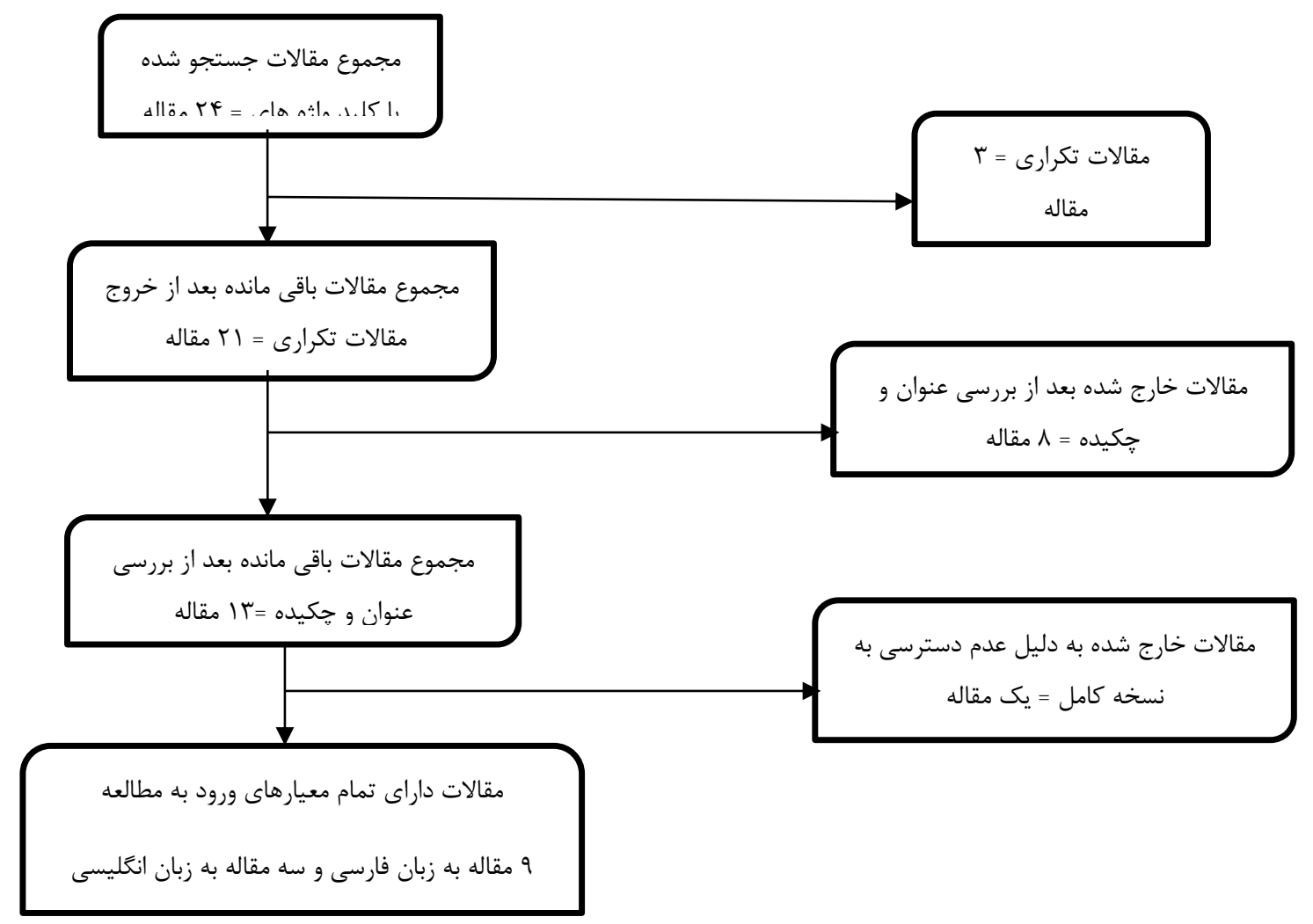

شكل شماره ا: روش انتخاب مقالات

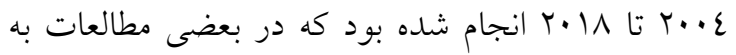

مطالعات متعددى به شكل توصيفى (از نوع همبستكى، شده بود. در جدول شماره ا اطلاعات دقيقى در مورد هفت على - مقايسهاى، مورد- شاهدى)، نيمه تجربى و تجربى مطالعهى توصيفى و ينج مطالعهى مداخلهاى وارد شده در

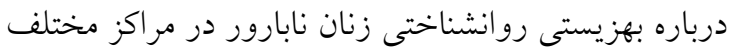
اين مطالعهى مرورى، ارائه شده است. نابارورى، كلينكها و مطبهاى خصوصى كشور از سال

جدول شماره ا: برخى مطالعات انجام شده در رابطه با بهزيستى روانشناختى زنان نابارور در ايران 


\begin{tabular}{|c|c|c|c|c|c|}
\hline نتايج & نمونهها و نحوه جمع آورى & محل مطالعه و شهر نمونه گيرى & 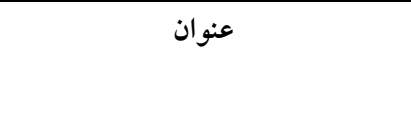 & نويسند انان (سال) & رديف \\
\hline 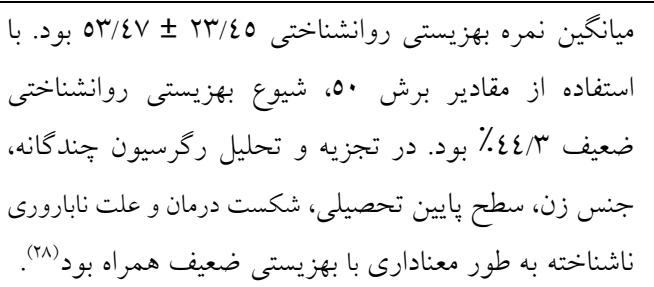 & 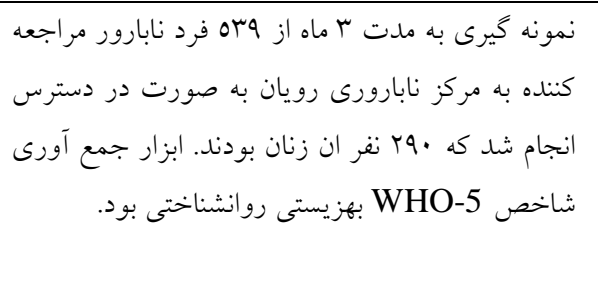 & مقطعى، تهران & افواد نامل مرتبط با بهزيستى ضعيف در & 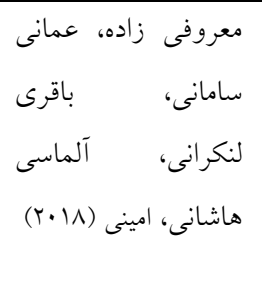 & 1 \\
\hline 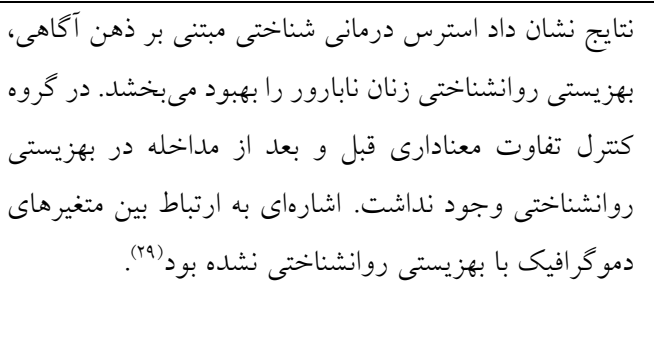 & 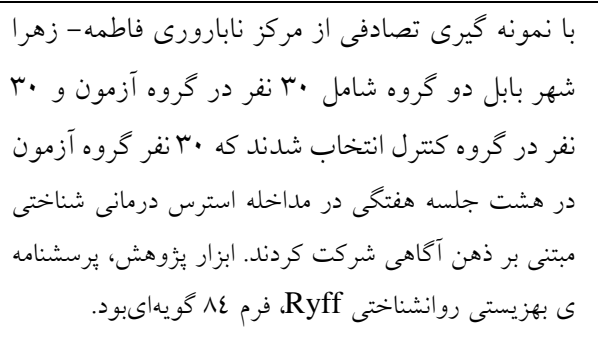 & تجربى، بابل & 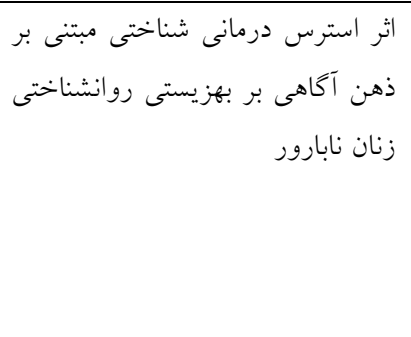 & كوشه، & r \\
\hline 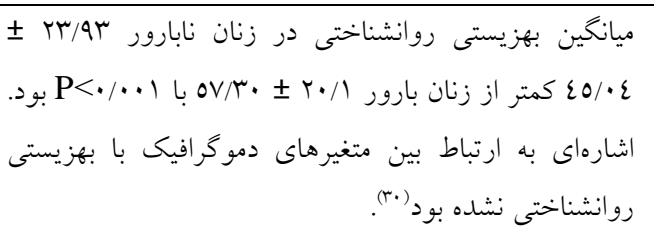 & 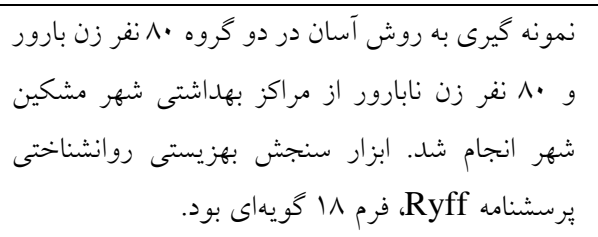 & مشلى - مقين مقايسهاى، & 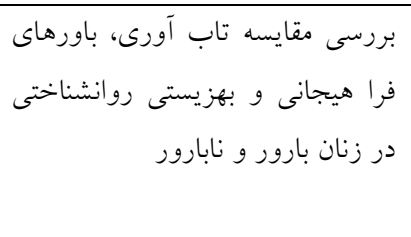 & جبرائيلى، هاشمى، & r \\
\hline 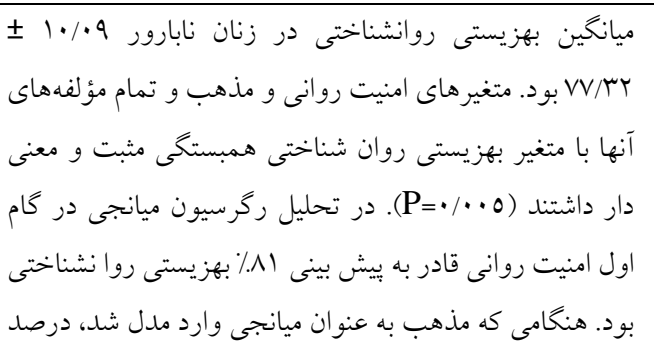 & 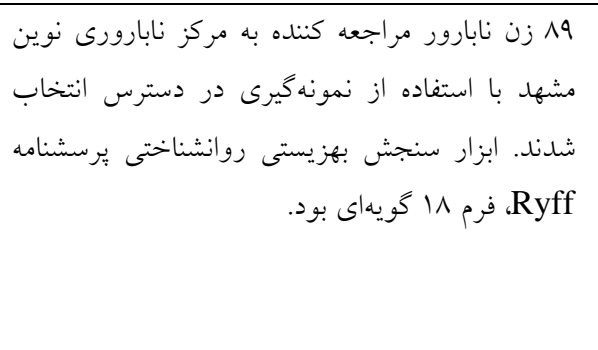 & هوصيفى از نونى مشهد & 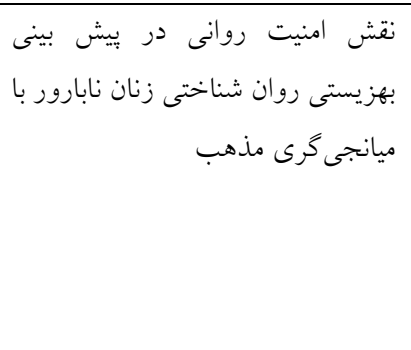 & 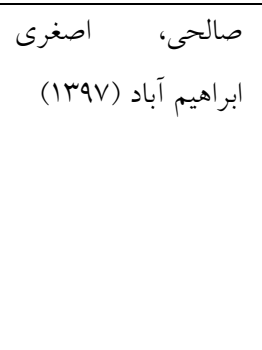 & $\varepsilon$ \\
\hline
\end{tabular}




\begin{tabular}{|c|c|c|c|c|c|}
\hline 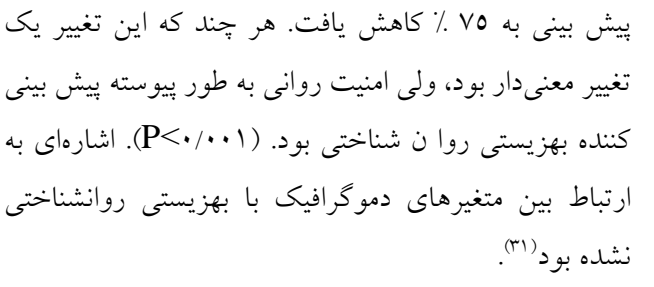 & & & & & \\
\hline 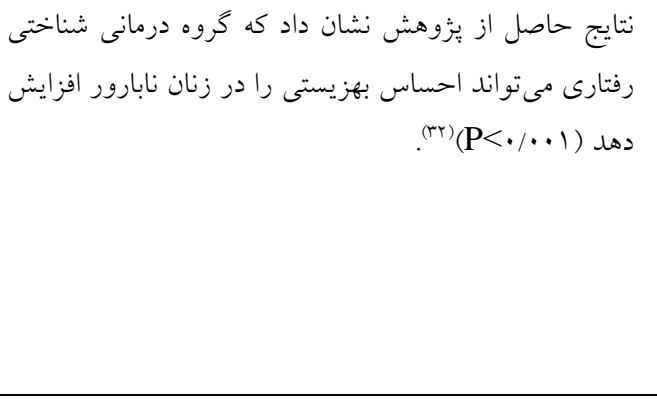 & 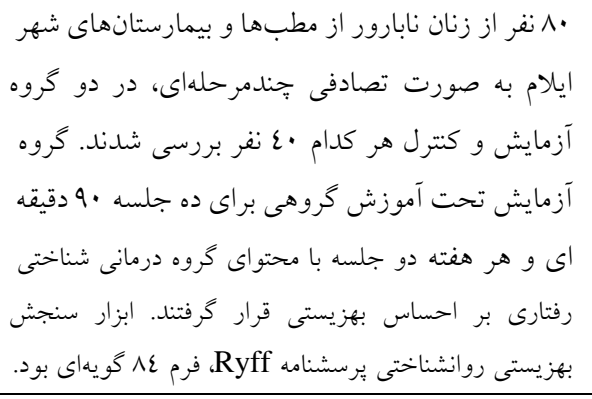 & 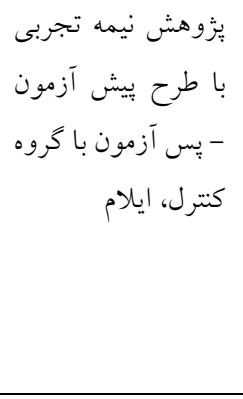 & 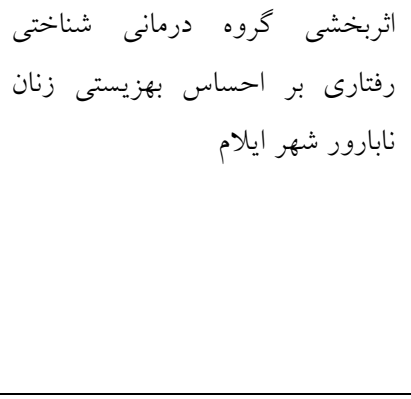 & مقدم (I I I الهى، موسوى & 0 \\
\hline 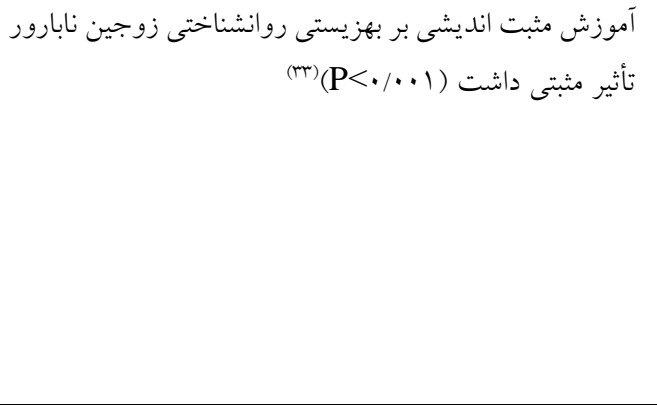 & 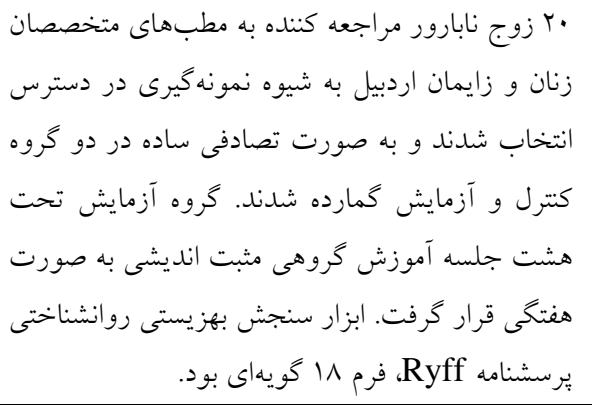 & 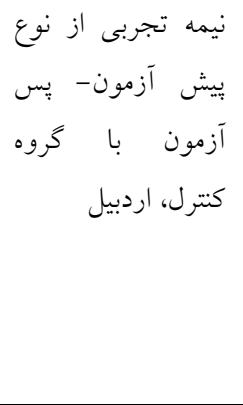 & 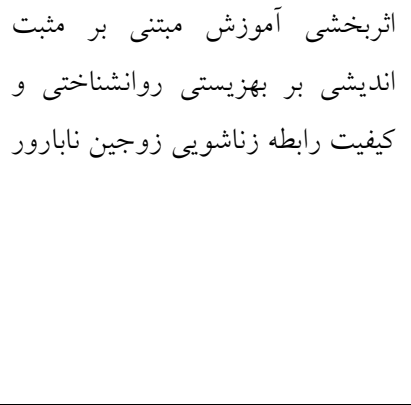 & زدرگاهى، محسن زاده، & 7 \\
\hline 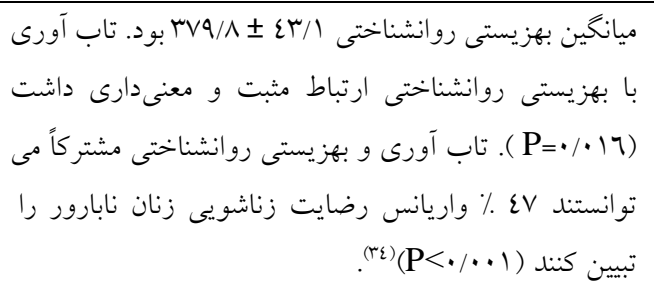 & 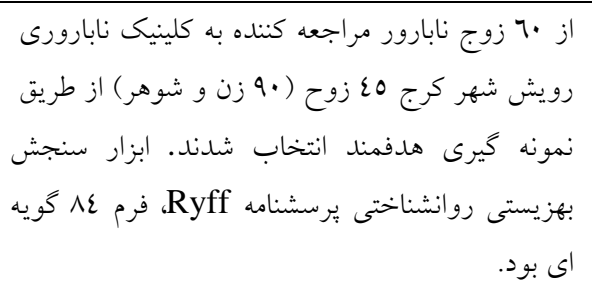 & توصيفى - & 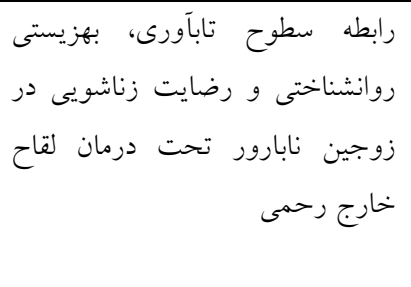 & نون & $\mathrm{V}$ \\
\hline
\end{tabular}




\begin{tabular}{|c|c|c|c|c|c|}
\hline 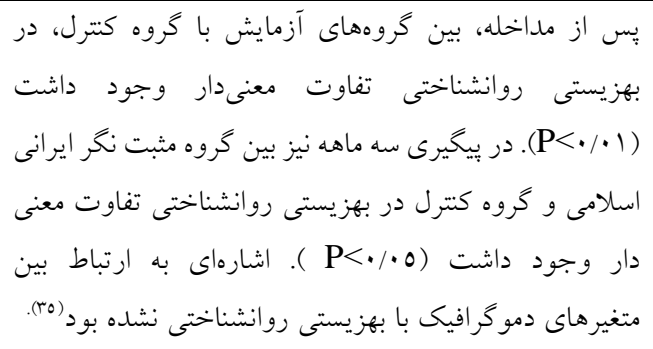 & 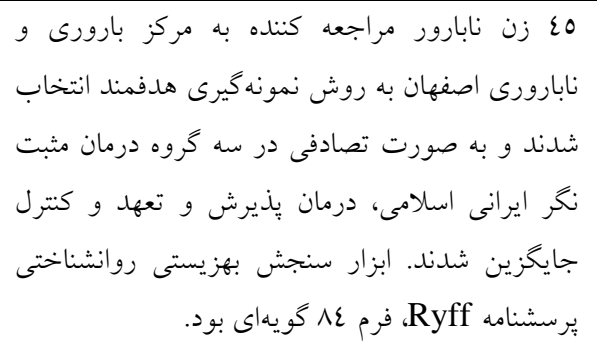 & 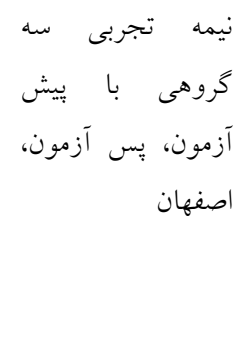 & 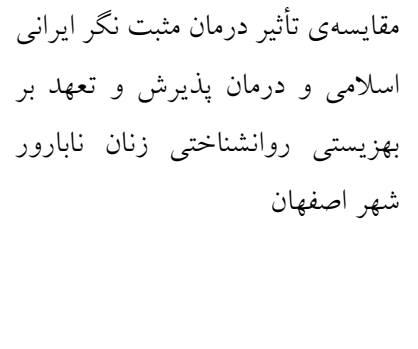 & 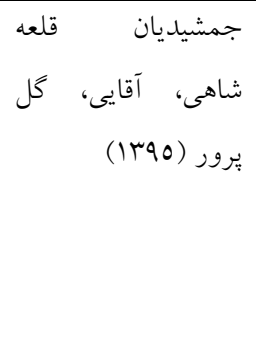 & \\
\hline 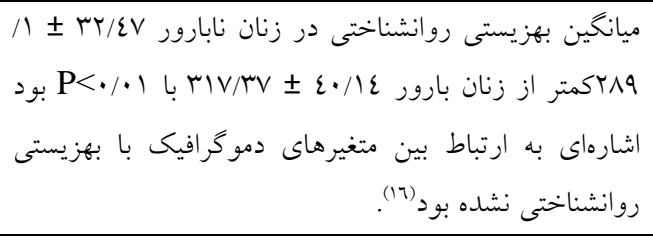 & 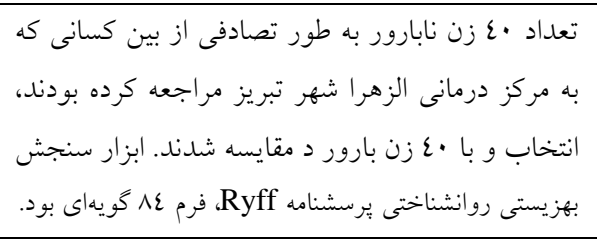 & تعلى - مقايسهاى، & 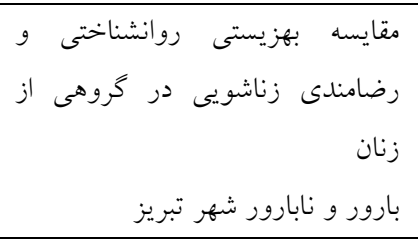 & هاتملوى سعدآبادى، & 11 \\
\hline 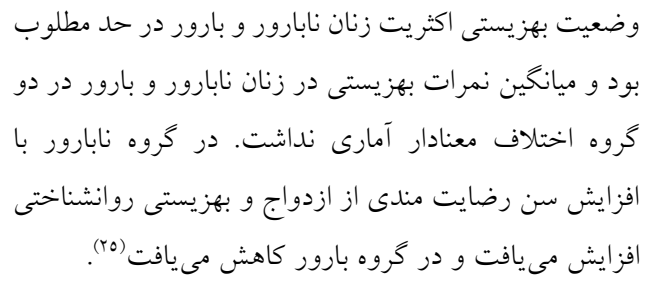 & 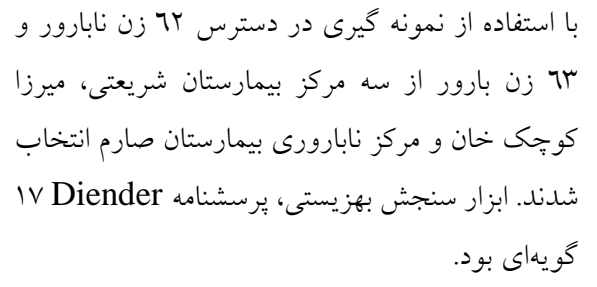 & - مطلعه به روش مورد & رضايت مندى راز ازدواج نابارورى با بهزيستى و & 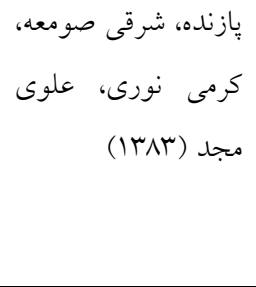 & $1 T$ \\
\hline
\end{tabular}


اين دو مطالعه نيز از ابزار بهزيستى روانشناختى Ryff

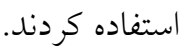
يافتهاى دو مطالعهاى كه از ابزارهاى ديخرى غير از ابزار

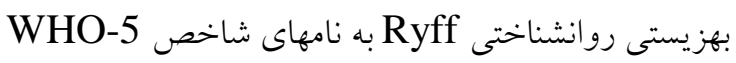
بهزيستى روانشناختى و برسشنامه سنجش بهزيستى استفاده كردند، نشان دادند ب/ Diender

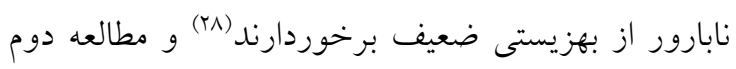

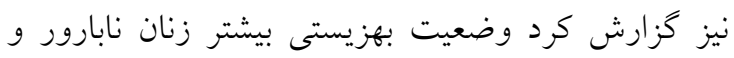

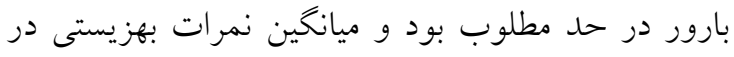

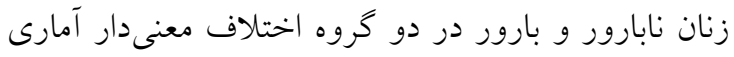

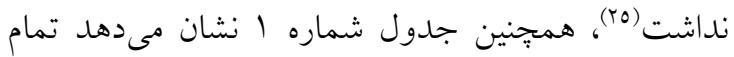
مطالعاتى كه مداخلهاى به شكل هاى مختلف شامل: استرس هلمس درمانى شناختى مبتنى بر ذهن آكاهى، گروه درمانى شناختى

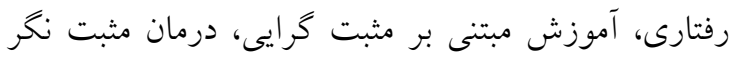

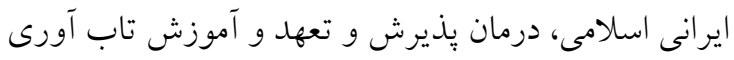

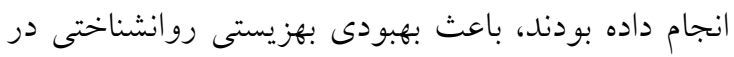

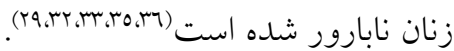

\section{بحث و نتيجه تيرى}

در مجموع مىتوان كفت نتايج مطالعاتى كه در سالهاى

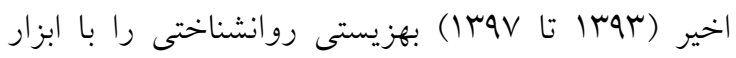
بهزيستى روانشناختى Ryff سنجيدند، نشان مىدهند بهزيستى روانشناختى زنان نابارور افزايش يافته است، جون

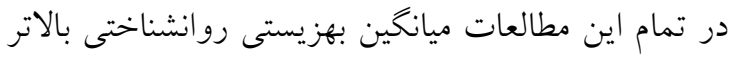

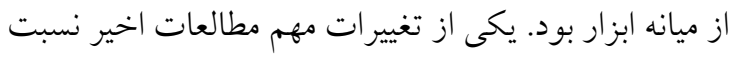
به مطالعات كذشته، افزايش سطح تحصيلات شركت كنندگان بود. Zurlo و همكاران در مطالعهى خود بر سطح

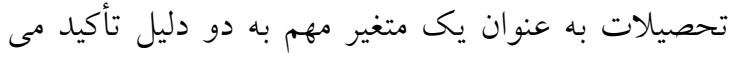
كنند. دليل اول ارتباط آن با درك بيشتر نابارورى و كنترل درمانهاى يزشكى و دليل دوم به خاطر ديخر جنبهاى شاد زندگى به غير از مادرى كه امروزه در نظر گرفته مى شود (^^). از طرف ديخر سطح تحصيلات فرد نابارور در نحوه مقابله

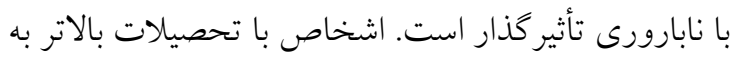

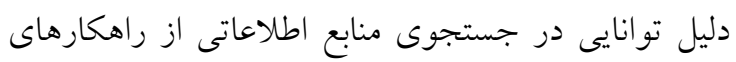

جدول شماره ا نشان مىدهد مطالعات در مر اكز نابارورى،

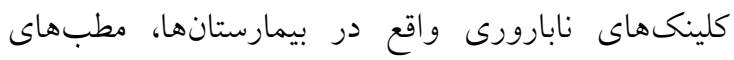

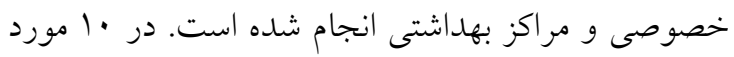

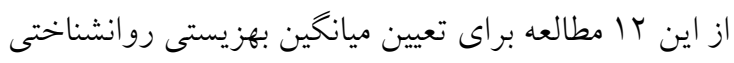

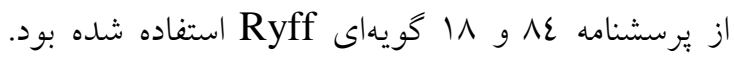

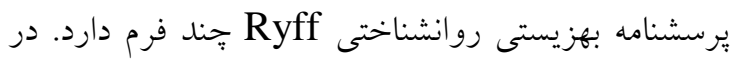
فرم بلند خود • با كويه دارد، علاوه بر آن فرمهاى كوتاه

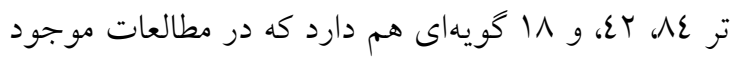

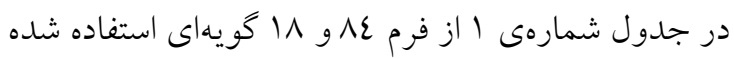
است. در تمام نسخههاى اين برسشنامه نمره بالاتر، بهزيستى روانشناختى بهتر را نشان مىدهد. اين برسشنامه نقطه برش هم ندارد. از آنجايى كه براى سنجش بهزيستى لهدرد روانشناختى در زنان نابارور در برخى مطالعات از نسخهى عه كويهاى ابزار سنجش بهزيستى روانشناختى Ryff و در بعضى ديخر

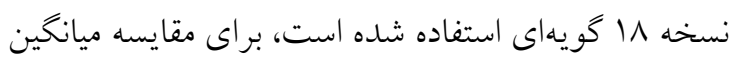

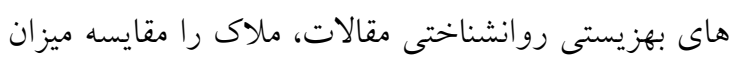
درصدى كه ميانگين بهزيستى روانشناختى بالاتر از ميانه ابزار مربوطه بود، قرار داديم.

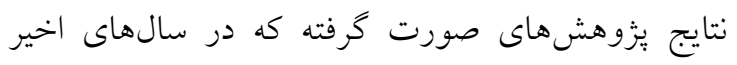

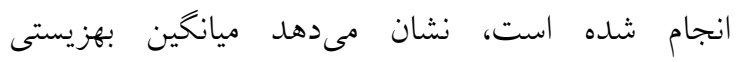
روانشناختى زنان نابارور ايرانى بالاتر از ميانه ابزار است.

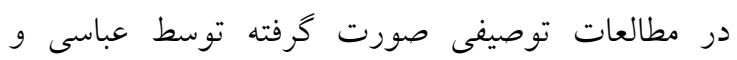

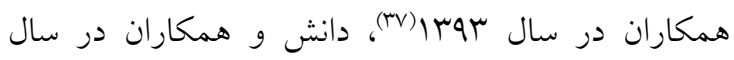


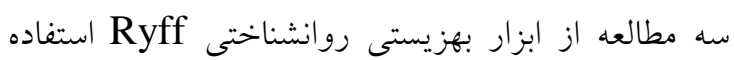

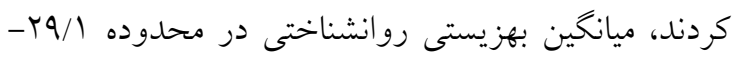
9/9 بالاتر از ميانه ابزار بود. نتايج دو مطالعهى على - مقايسهاى كه يكى در سال

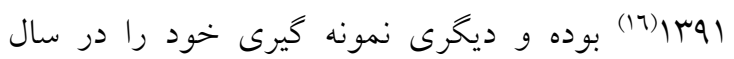

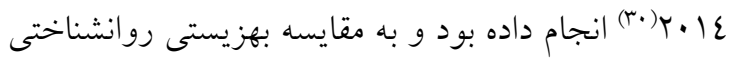
زنان بارور و نابارور يرداخته است، نشان مىدهد ميانخين

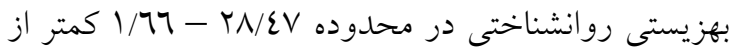

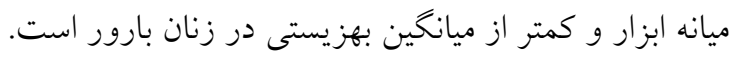


تضمين كننده بقاى زندگى زناشويى و از سويى ديخر تكميل كننده زندكى فرد و تحقق داستان بارورى اوست.

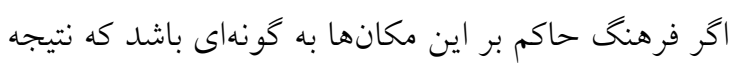

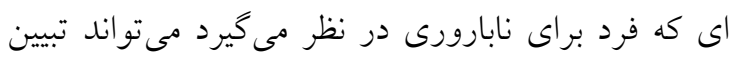

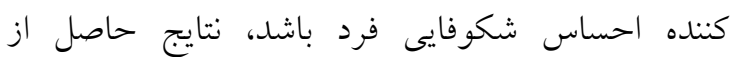
نابارورى اثر كذارتر خو اهد بود (عَ). به باور صاحب نظران عوامل زمينهاى مانند زمان، تغيير و تحول و منابع شخصى ممكن است تشكيل دهنده الخوهاى

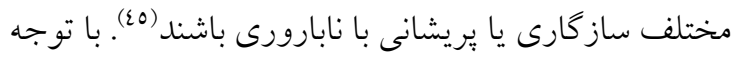

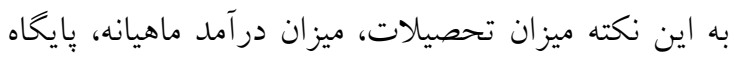
اقتصادى- اجتماعى و محل سكونت ارتباط معنى دارى با باليال بهزيستى روانشناختى دارند، آن دسته از زوجين نابارور كه

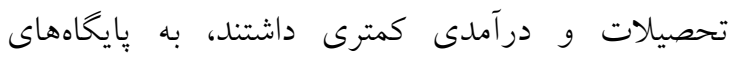
اجتماعى- اقتصادى يايينترى متعلق بودند و در مناطق روستايى سكونت داشتند در مقايسه با ساير ياسخكويان

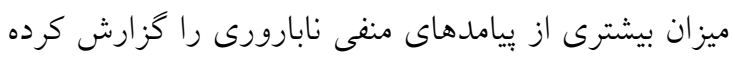

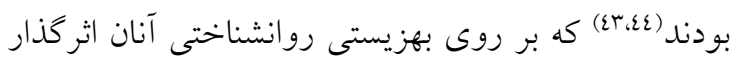

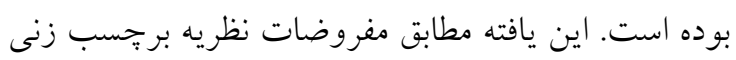

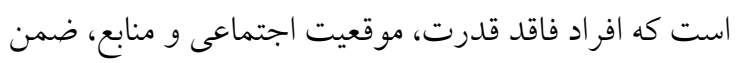

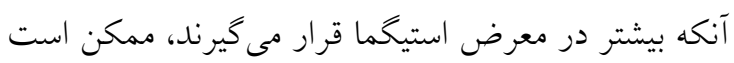

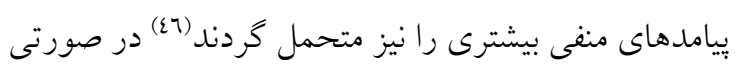

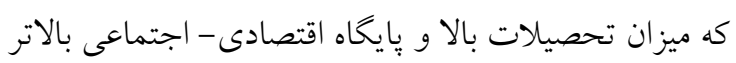

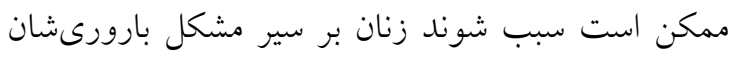
كنترل بيشترى احساس كنند و در نتيجه بهزيستى بالاتر و آشفتكى كمترى را گزارش مى كنند (LY،VV). مشابه يافتهاى مطالعات تجربى و نيمه تجربى انجام يافته در ايران بر روى متغير بهزيستى روانشناختى، نتايج يزوهش هايى كه در نقاط ديخر دنيا انجام شده، نشان مىدهد

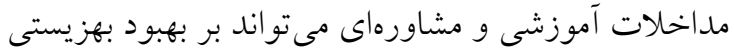
روانشناختى در زنان نابارور مؤثر باشد. مداخلات اين يُزوهشها مشابه مطالعات انجام كرفته در ايران مانند

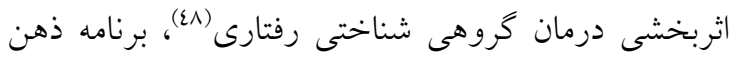

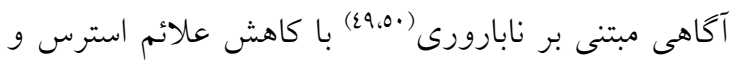
افسردگى و افزايش بهزيستى در زنان نابارور همراه بودند.
مقابلهاى مبتنى بر حل مسئله بيشترى در برابر راهكارهاى

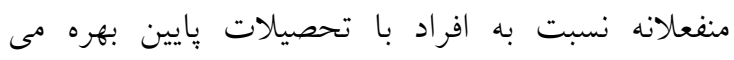

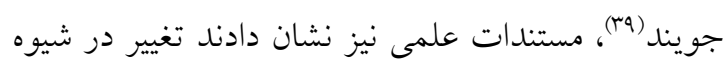

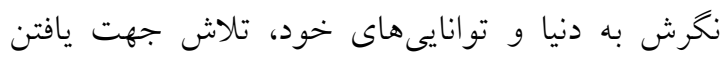

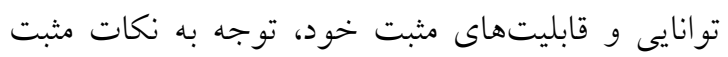

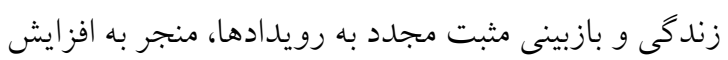
شادى در افراد مى شود. افرادى كه حوادث منفى را در

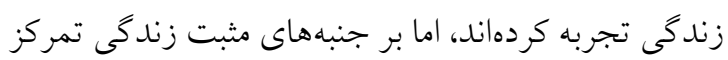

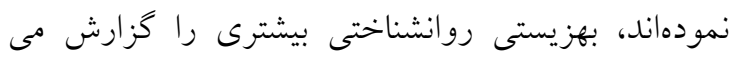
كنند (2) (2) (2). در بين مطالعات، يُزوهشهايى كه در شهر تبريز (17) و

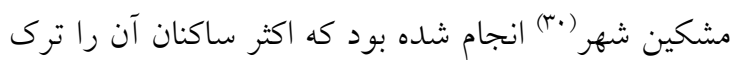

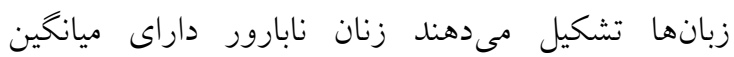

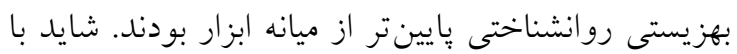

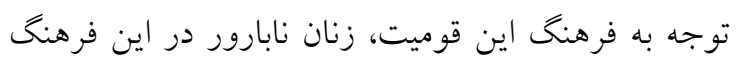

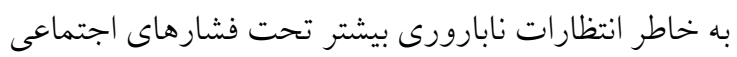

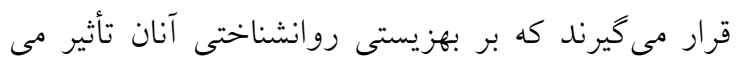

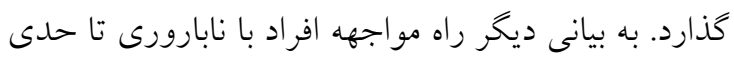

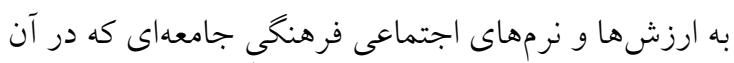

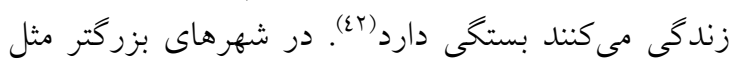

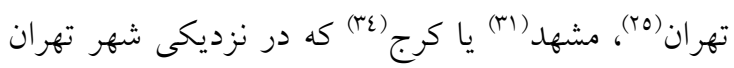
مىباشد و فرهنكى مشابه با شهر تهران دارد، ميانگين بهزيستى روانشناختى زنان نابارور بالاتر از ميانه ابزار بود.

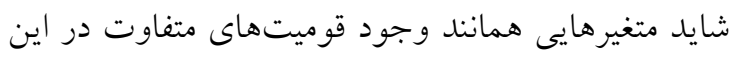
شهرها به ويزه فارس زبانها، سطح تحصيلات بالاتر زنان هان

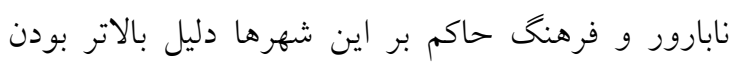

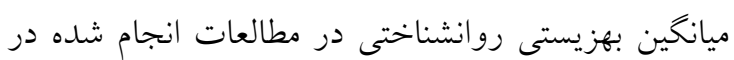

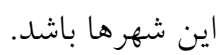
نتايج بعضى مطالعات نيز نشان دادند كه زنان و زوجين نابارورى كه در مناطق روستايى يا شهرهاى كوجى لهیى سكونت داشتند در مقايسه با ساير پاسخخويان ميزان

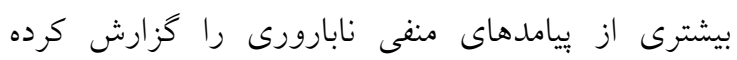

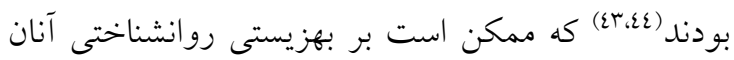
تأثير گذار است. شايد در مكانهاى كو گكتر بارورى بيشتر 


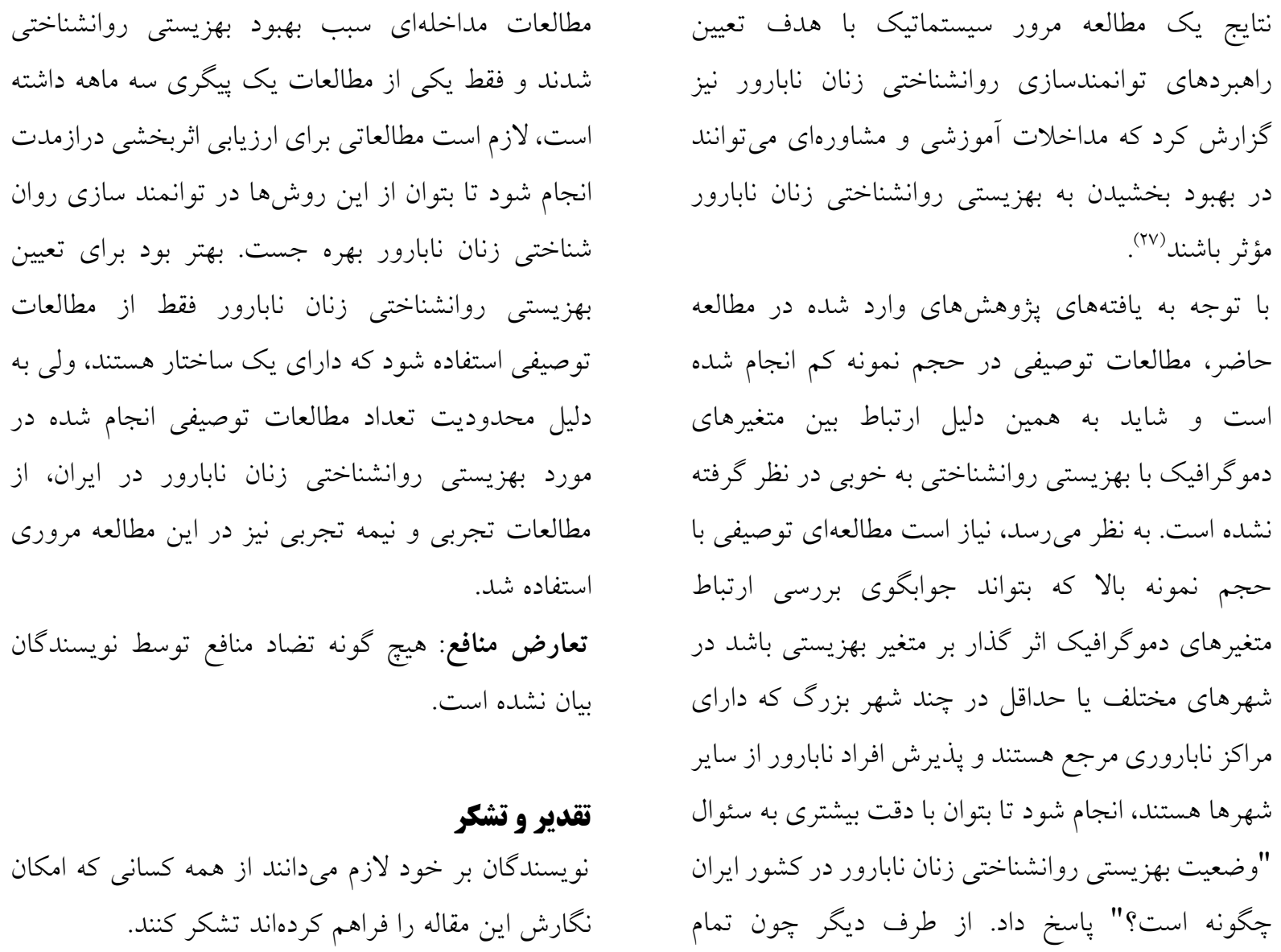

\section{References}

1. Gdańska P, Drozdowicz-Jastrzębska E, Grzechocińska B, Radziwon-Zaleska M, Węgrzyn P, Wielgoś M. Anxiety and depression in women undergoing infertility treatment. Ginekologia polska. 2017;88(2):109-12.

2. Luk BH, Loke AY. The impact of infertility on the psychological well-being, marital relationships, sexual relationships, and quality of life of couples: a systematic review. J Sex Marital Ther. 2015;41(6):610-25.

3. Lee GL, Blyth ED, Chan CL. Understanding the patterns of adjustment to infertility of IVF users using narrative and autobiographical timeline. Asian Pacific Journal of Reproduction. 2012;1(2):125-34.

4. Ombelet W, Van Blerkom J, Klerkx E, Janssen M, Dhont N, Mestdagh G, Nargund G, Campo R. The tWE lab simplified IVF procedure: First births after freezing/thawing. Facts views vis ObGyn. 2014;6(1):45-9.

5. Mormandi EA, Otero P, Bertone AL, Calvo M, Astarita G, Kogovsek N, Levalle O. Body weight increase and quality of semen: A controversial association. Endocrinología y Nutrición (English Edition). 2013;60(6):303-7.

6. Ardekani AM, Chaharsoughi SA. P-48: Infertility and Stress. Int J Fertil Steril. 2010;4(2-1).

7. Akhondi MM, Kamali K, Ranjbar F, Shirzad M, Shafeghati S, Ardakani ZB, Goodjani A, Parsaeian M, Mohammad K. Prevalence of primary infertility in Iran in 2010. Iranian journal of public health. 2013;42(12):1398.-404. [Persian]

8. Linley PA, Maltby J, Wood AM, Osborne G, Hurling R. Measuring happiness: The higher order factor structure of subjective and psychological well-being measures. Personality and individual differences. 2009;47(8):878-84.

9. Simonton DK, Baumeister RF. Positive psychology at the summit. Rev Gen Psychol. 2005;9(2):99-102.

10. Keyes CL, Shmotkin D, Ryff CD. Optimizing well-being: the empirical encounter of two traditions. J pers soc psychol. 2002;82(6):1007-22. 
11. Safarinia M, Aghayousefi AR, Baradaran M. The relationship between personality aspects, problem solving and psychological well-being the role of narcissism. Counsel Psychother Culture. 2014. 2014;5:89-102.

12. Dargahi SH, Zeraati M, Ghamari Givi H, Ayadi N, Haghanni M. The effectiveness of emotion regulation training on emotional well-Being and marital satisfaction of infertile women. Iran Journal of Nursing. 2015;28(93):151-62. [Persian]

13. Powell J, Hamborg T, Stallard N, Burls A, McSorley J, Bennett K, Griffiths KM, Christensen H. Effectiveness of a web-based cognitive-behavioral tool to improve mental well-being in the general population: randomized controlled trial. J Med Internet Res. 2013;15(1):e2.

14. Bridges LJ, Margie NG, Zaff JF. Background for community-level work on emotional well-being in adolescence: Reviewing the literature on contributing factors. ERIC Clearinghouse; 2001 Dec.; 1-32.

15. Volgsten H, Svanberg AS, Ekselius L, Lundkvist Ö, Poromaa IS. Risk factors for psychiatric disorders in infertile women and men undergoing in vitro fertilization treatment. Fertility and Sterility. 2010;93(4):1088-96.

16. Hatamloye SM, Hashemi NT. The comparison of psychological well-being and marital satisfaction in the fertile and infertile women. Journal of Health Psychology. 2012;1(1):20-31. [Persian]

17. Souter VL, Hopton JL, Penney GC, Templeton AA. Survey of psychological health in women with infertility. J Psychosom Obstet Gynecol. 2002 Jan 1;23(1):41-9.

18. Hahn CS. Psychosocial well-being of parents and their children born after assisted reproduction. Journal of Pediatric Psychology. 2001;26(8):525-38.

19. Karaca A, Unsal G. Psychosocial problems and coping strategies among Turkish women with infertility. Asian Nurs Res. 2015;9(3):243-50.

20. Valoriani V, Lotti F, Lari D, Miccinesi G, Vaiani S, Vanni C, Coccia ME, Maggi M, Noci I. Differences in psychophysical well-being and signs of depression in couples undergoing their first consultation for assisted reproduction technology (ART): an Italian pilot study. Eur J Obstet Gynecol Reprod Biol. 2016;197:179-85.

21. Hasanpoor-Azghdy SB, Simbar M, Vedadhir A. The social consequences of infertility among Iranian women: a qualitative study. Int j fertil steril. 2015;8(4):409-20.

22. Kazemian Z, Behmani N, Zadehbaghri L, Abalfath M. The efficacy of Self-regulation couple therapy on marital intimacy among infertile women. Armaghane danesh. 2013;18(5):368-79. [Persian]

23. Wischmann T, Stammer H, Scherg H, Gerhard I, Verres R. Psychosocial characteristics of infertile couples: a study by theHeidelberg Fertility Consultation Service'. Human reproduction. 2001;16(8):1753-61.

24. Kowalcek I, Wihstutz N, Buhrow G, Diedrich K. Subjective well-being in infertile couples. $J$ Psychosom Obstet Gynecol. 2001;22(3):143-8.

25. Pazandeh F, Sharghisomeah N, Karaminori R, Alavimajd H. Investigate the relationship between infertility with well-being and satisfaction of marriage. Pajoohandeh Journal. 2004;9(6):9-15. [Persian]

26. Ryff CD. Psychological well-being revisited: Advances in the science and practice of eudaimonia. Psychother psychosom. 2014;83(1):10-28.

27. Taebi M, Simbar M, Abdolahian S. Psychological empowerment strategies in infertile women: A systematic review. J Educ Health Promot. 2018;7(68):1-7.

28. Maroufizadeh S, Omani-Samani R, Bagheri-Lankarani N, Almasi-Hashiani A, Amini P. Factors associated with poor well-being of infertile people: a cross-sectional study. Middle East Fertil Soc J. 2018;23(4):468-70.

29. Fard TR, Kalantarkousheh M, Faramarzi M. Effect of mindfulness-based cognitive infertility stress therapy on psychological well-being of women with infertility. Middle East Fertil Soc J. 2018;23(4):476-81.

30. Jebraeili H, Hashemi J, Nazemi A. A comparative study of resilience, meta-emotional beliefs, and psychological well-being in fertile and infertile women. Journal of Fundamentals of Mental Health. 2016;18(5):259-64.

31. Salehi B, Asghari Ebrahimabad MJ. Role of Psychological Security in Predicting Psychological Well-Being of Infertile Women with Mediation of Religion. Islamic Life Style Centered on Health. 2018;2(4):195-201. [Persian] 
32. Nasrolahi H, Mousavimoghadam SR. The effectiveness of cognitive behavioral group therapy on the sense of well-being among infertile women of Ilam. Medical Science Journal of Islamic Azad Univesity-Tehran Medical Branch. 2018;28(4):313-8. [Persian]

33. Dargahi SH, Mohsen Zade F, Zahrakar K, Didehban M. Effect of Positive Thinking Training on Psychological well- being and Marital Relationship Quality of Infertile Couple. Journal of Disability Studies. 2017; 97(7):1-7. [Persian]

34. Danesh E, Aminalroayaei P, Nooripour LR. The Relationship between Resiliency, Psychological Well-being and Marital Satisfaction of Infertile Couples Undergoing in Vitro Fertilization. Community Health. 2017; 4(3):170-8. [Persian]

35. Aghaei A, Golparvar M. Comparison of Effect Iranian-Islamic Positive Therapy with Acceptance and Commitment Therapy on Psychological Well-Being of Infertile Women in Isfahan City. Journal of Urmia Nursing And Midwifery Faculty. 2017;15(1):48-57. [Persian]

36. Behzadpoor S, Vakili M, Sohrabi F. The Effect of resilience training on increasing psychological well-being of infertile women. scientific journal of ilam university of medical sciences. 2015;23(5):131-42. [Persian]

37. Abbasi M, Dargahi SH, Mehrabi A, Ghasemi Jobaneh R, Dargahi A. Role of meta emotion and resiliency in psychological the well-being of infertile women of Gonabad City in 2012-2013. Community health journal. 2014;8(1):9-17. [Persian]

38. Zurlo MC, Della Volta MF, Vallone F. Predictors of quality of life and psychological health in infertile couples: the moderating role of duration of infertility. Quality of Life Research. 2018;27(4):945-54.

39. Hasanpoor-Azghdy SB, Simbar M, Vedadhir A. The emotional-psychological consequences of infertility among infertile women seeking treatment: Results of a qualitative study. Iranian journal of reproductive medicine. 2014;12(2):131-8. [Persian]

40. Pictet A, Coughtrey AE, Mathews A, Holmes EA. Fishing for happiness: The effects of generating positive imagery on mood and behaviour. Behaviour research and therapy. 2011;49(12):885-91.

41. Hariri M, Khodami N. A study of the efficacy of teaching happiness Based on the Fordyce method to elderly people on their life expectancy. Procedia Soc Behav Sci. 2011;30:1412-5.

42. Zahraie S, Bahrami Eh, Kormi Nr, Besharat Ma, Bidadian M. The Role Of Cognitive Representation, Personality And Cause Of Infertility In Predicting Psychological Wellbeing Of Infertile Women. Journal of Research Behavioral Sciences. 2015;12(4): 520-34. [Persian]

43. Hasanpoor-Azghady SB, Simbar M, Vedadhir AA, Azin SA, Amiri-Farahani L. The Social Construction of Infertility Among Iranian Infertile Women: A Qualitative Study. Journal of Reproduction \& Infertility. 2019;20(3):178-91. [Persian]

44. Riahi ME, Zarezade ME. A study on the gender differences in psycho-social consequences of infertility: infertile couples using Yazd'Infertility Center Services. Women's Strategic Studies. 2012; 14(56): 155-210. [Persian]

45. Moura-Ramos M, Gameiro S, Canavarro MC, Soares I, Almeida-Santos T. Does infertility history affect the emotional adjustment of couples undergoing assisted reproduction? The mediating role of the importance of parenthood. Br J Health Psychol. 2016;21(2):302-17.

46. Goffman E. Stigma: notes on the management of spoiled identity Simon and Schuster. New York. 1963:3.

47. Gourounti K, Anagnostopoulos F, Potamianos G, Lykeridou K, Schmidt L, Vaslamatzis G. Perception of control, coping and psychological stress of infertile women undergoing IVF. Reprod BioMed Online. 2012;24(6):670-9.

48. Karaca A, Yavuzcan A, Batmaz S, Cangür Ş, Çalişkan A. The Effect of Cognitive Behavioral Group Therapy on Infertility Stress, General Health, and Negative Cognitions: A Randomized Controlled Trial. J Ration Emot Cogn Behav Ther. 2019:1-20.

49. Nery SF, Paiva SP, Vieira ÉL, Barbosa AB, Sant'Anna EM, Casalechi M, Dela Cruz C, Teixeira AL, Reis FM. Mindfulness-based program for stress reduction in infertile women: Randomized controlled trial. Stress and Health. 2019;35(1):49-58.

50. Galhardo A, Moura-Ramos M, Cunha M, Pinto-Gouveia J. How Does the Mindfulness-Based Program for Infertility (MBPI) Work in Reducing Depressive Symptoms?. Mindfulness. 2018;9(2):629-35. 